\title{
Effectiveness of the blue led in the photoinactivation of Staphylococcus aureus and
}

\section{Staphylococcus epidermidis in vitro}

\section{Eficácia do led azul na fotoativação de Staphylococcus aureus e Staphylococcus epidermidis in vitro \\ Eficacia del led azul en la fotoactivación de Staphylococcus aureus y Staphylococcus epidermidis in} vitro

Juliana Teixeira Pedroso

ORCID: https://orcid.org/0000-0002-2521-1352 Universidade do Vale do Paraíba, Brazil

E-mail: juliana.teixeira.pedroso@hotmail.com

Edna Ponce

ORCID: https://orcid.org/0000-0002-8658-4363

Universidade do Vale do Paraíba, Brazil

E-mail: ponce0702@gmail.com

Isabelle de Paula Ribeiro

ORCID: https://orcid.org/0000-0002-4278-9594 Universidade do Vale do Paraíba, Brazil

E-mail: isabelle.isa27@gmail.com

Juliana Guerra Pinto

ORCID: https://orcid.org/0000-0002-7356-1576

Universidade do Vale do Paraíba, Brazil

E-mail: juguerra@univap.br

Alejandro Guillermo Miñán

ORCID: https://orcid.org/0000-0001-8864-8415

Facultad de Ciencias Exactas, Argentina E-mail: agminan@gmail.com

Juliana Ferreira-Strixino

ORCID: https://orcid.org/0000-0001-7128-6817 Universidade do Vale do Paraíba, Brazil E-mail: juferreira@univap.br

\begin{abstract}
One possibility of treatment in Aesthetics for folliculitis is a blue LED, as it acts on microbial control. Studies describe that the blue LED, with 405-470nm wavelength, has a bactericidal effect when irradiated in certain bacteria such as Staphylococcus aureus. This study aimed to evaluate the $450 \mathrm{~nm}$ blue LED's efficacy as a modality in aesthetic treatments in the photoinactivation of the planktonic strains of S. aureus and S. epidermidis with power densities of 97 , 110, 156, and $200 \mathrm{~mW} / \mathrm{cm} 2$ in different energy densities. Bacterial suspensions of S. aureus (ATCC 25923) and S. epidermidis (ATCC 12228) were plated in 24-well plates and irradiated with other energy and power densities. After irradiation, each bacterial suspension was diluted in a phosphate buffer solution in a 96-well plate. Aliquots of $10 \mu \mathrm{L}$ were collected from this dilution and streaked, in triplicate, in Brain Heart Infusion agar plates and incubated for $24 \mathrm{~h} / 37^{\circ} \mathrm{C}$. CFU counts were expressed in $\log 10 / \mathrm{mL}$ and submitted to ANOVA and Tukey statistical tests. The energy and power densities used were insufficient to cause an antimicrobial effect on S. aureus or S. epidermidis planktonic cultures with a single light application.
\end{abstract}

Keywords: Phototherapy; Blue led; Staphylococcus aureus; Staphylococcus epidermidis; Antimicrobial; Photoinactivation.

\section{Resumo}

Uma possibilidade de tratamento em Estética para foliculite é o uso do LED azul, pois atua no controle microbiano. Estudos descrevem que o LED azul, com comprimentos de onda de 405-470nm, tem efeito bactericida quando irradiado em determinadas bactérias como Staphylococcus aureus. Este estudo teve como objetivo avaliar a eficácia dos LED's azuis de $450 \mathrm{~nm}$ como modalidade em tratamentos estéticos na fotoinativação das cepas planctônicas de $S$. aureus e $S$. epidermidis com densidades de potência de 97, 110, 156 e $200 \mathrm{~mW} / \mathrm{cm} 2 \mathrm{em}$ diferentes densidades de energia. Suspensões bacterianas de S. aureus (ATCC 25923) e S. epidermidis (ATCC 12228) foram semeadas em placas de 24 poços e irradiadas com diferentes densidades de energia e potência. Após a irradiação, cada suspensão bacteriana foi diluída em uma solução tampão de fosfato em uma placa de 96 poços. Alíquotas de $10 \mu \mathrm{L}$ foram coletadas desta diluição 
e semeadas, em triplicata, em placas de ágar Brain Heart Infusion e incubadas por $24 \mathrm{~h} / 37^{\circ} \mathrm{C}$. As contagens de UFC foram expressas em $\log 10 / \mathrm{mL}$ e submetidas aos testes estatísticos ANOVA e Tukey. As densidades de energia e potência utilizadas foram insuficientes para causar efeito antimicrobiano em culturas planctônicas de $S$. aureus ou $S$. epidermidis com uma única aplicação de luz.

Palavras-chave: Fototerapia; Led azul; Staphylococcus aureus; Staphylococcus epidermidis; Antimicrobiano; Fotoinativação.

\section{Resumen}

Un posible tratamiento para la foliculitis, empleado en estética, es el uso de radiación LED azul ya que limita el crecimiento microbiano. Diversos estudios han reportado que la radiación LED azul, con longitudes de onda en el rango de 405-470nm, tiene un efecto bactericida sobre ciertos patógenos bacterianos como Staphylococcus aureus. El presente estudio tiene por objeto evaluar la eficacia de la radiación LED azul a $450 \mathrm{~nm}$ (usada habitualmente en tratamientos estéticos) en la fotoinactivación de cultivos planctónicos de S. aureus y S. epidermidis empleando diferentes densidades de potencia $(97,110,156$ y $200 \mathrm{~mW} / \mathrm{cm} 2)$ y densidades de energía. Las suspensiones bacterianas de S. aureus (ATCC 25923) y S. epidermidis (ATCC 12228) se sembraron en placas de 24 pocillos y se irradiaron con diferentes densidades de energía y potencia. Finalizada la irradiación, se llevó a cabo la enumeración de cada suspensión bacteriana por dilución seriada en solución buffer fosfato. Luego se tomaron alícuotas de $10 \mu \mathrm{L}$ de cada dilución para sembrarlas en placas de agar infusión Cerebro-Corazón y se incubaron durante 24 h a $37^{\circ} \mathrm{C}$. Los recuentos de UFC se expresaron en escala $\operatorname{logarítmica}(\log 10 / \mathrm{mL})$ y se realizó el análisis estadístico de ANOVA y test de Tukey. Los resultados indicaron que las densidades de energía y potencia utilizadas fueron insuficientes para causar un efecto antimicrobiano en cultivos planctónicos de S. aureus o S. epidermidis con una sola aplicación de radiación azul.

Palabras clave: Fototerapia; Led azul; Staphylococcus aureus; Staphylococcus epidermidis; Agente antimicrobiano; Fotoinactivación.

\section{Introduction}

Bacterial infections have been a constant concern in public health. As bacteria develop antibiotic resistance, it significantly increases hospitals' morbidity and mortality, leading to alternative treatments. Skin infections are very prevalent in clinical practice and have an effective presentation, etiology, and severity variability. Most cases of bacterial skin infection are caused by Gram-positive bacteria such as Staphylococcus aureus (Lister \& Horswill, 2014). Folliculitis is a skin condition that affects the hair follicle, usually caused by S. aureus bacteria generating acne-like lesions, manifested by pus, follicular hyperemia, and may or may not present pain (Albuquerque et al., 2019). S. aureus lives commensally on the skin, nodules, and human mucosa as an opportunistic pathogen that can infect, invade, persist and replicate in many humans. It is a Gram-positive, aerobic, spherically shaped bacteria called coconuts, with approximately 0.5 to $1.5 \mu \mathrm{m}$ in diameter, non-flagellate and organized in clusters, known to be very virulent and has a potent capacity to develop resistance to antibiotics (Bumah, Masson-Meyers, Cashin, \& Enwemeka, 2015; Rupel et al., 2019). This important infectious agent uses open wounds as an entry site for infections and can generate more severe invasive conditions (Monaco, Araujo, Cruciani, Coccia, \& Pantosti, 2017).

Staphylococcus epidermidis is a species best known as a symbiotic colonizer of the human skin microbiota, helping to protect this environment against pathogens and maintain balance with other diners. However, exogenous or endogenous factors, such as injury, stress, pollution, hormonal and $\mathrm{pH}$ changes, can affect skin homeostasis, favoring the development of inflammatory skin diseases such as acne, atopic dermatitis, rosacea, and psoriasis (Brown \& Horswill, 2020; Claudel et al., 2019).

Recent research seems to confirm the beneficial role of S. epidermidis in the pathophysiology of acne by limiting skin colonization by Cutibacterium acne and inflammation. However, the imbalance in favor of the S. epidermidis microorganism can also result in other health consequences, such as nosocomial infections at a rate almost as high as that of S. aureus (Claudel et al., 2019).

Blue LED therapy (Light Emitting Diode) has been gaining more and more space because of its microbial reduction capacity, with a non-pharmacological approach and without the involvement of exogenous photosensitizers (Dai et al., 2013, 2012). LED has proved to be an alternative to laser and has obtained approval for its use by the Food and Drug Administration (FDA) in the United States of America for not offering human risks. LED is safe, non-toxic, non-invasive, and there are no 
reports of side effects in the literature. Biological effects depend on parameters such as wavelength, energy density, power density, irradiation time, continuous or pulsed wave mode, and pulse patterns (Barolet, 2008).

One possibility of treatment in Aesthetics for folliculitis is a blue LED, as it acts on microbial control. It was described in previous studies that blue light (visible), with wavelengths of $405-470 \mathrm{~nm}$, when irradiated in certain bacteria such as $\mathrm{S}$. aureus, leads to a photosensitization of endogenous intracellular porphyrins that stimulate the production of reactive oxygen species, predominantly singlet oxygen (1O2), leading the cell to death. (Ashkenazi, Malik, Harth, \& Nitzan, 2003; Hamblin \& Hasan, 2004; Lipovsky, Nitzan, Gedanken, \& Lubart, 2010; Papageorgiou, Katsambas, \& Chu, 2000).

The objective of this study was to evaluate the efficacy of blue LED, as a modality of application in aesthetic treatments for photoinactivation of S. aureus and S. epidermidis strains, in vitro, with the wavelength of $450 \pm 10 \mathrm{~nm}$, at different energy densities.

\section{Methodology}

\subsection{Bacterial cultures and photo-inactivation treatments}

This study selected S. aureus and S. epidermidis as representative opportunistic pathogens responsible for skin infections. The strains of S. aureus (ATCC 25923) and S. epidermidis (ATCC 12228) were kept in a freezer at $-20{ }^{\circ} \mathrm{C}$ in Brain Heart Infusion (BHI) broth suspension containing 5\% glycerol. Each bacterial solution was first prepared by reactivating the strains later added to the BHI broth in conical Falcon-type tubes, remaining incubated for 24 hours in an incubator at $37^{\circ} \mathrm{C}$. The tubes were centrifuged at $3500 \mathrm{rpm}$ for 15 minutes, and the supernatant was discarded. Next, bacterial pellets of S. aureus and S. epidermidis were resuspended in sterile phosphate buffer solution (PBS) to obtain a bacterial density comparable to the 0.5 tubes on the MacFarland scale $(1.5 \times 108 \mathrm{CFU} / \mathrm{mL})$. In the case of S. epidermidis, the bacterial suspension was adjusted at $1.5 \mathrm{x}$ $108 \mathrm{CFU} / \mathrm{mL}$ by adding PBS. Both bacterial solutions were centrifuged at $3500 \mathrm{rpm}$ for 15 minutes, and the supernatant was discarded.

The contents of the tubes were resuspended with $300 \mu \mathrm{L}$ sterile PBS for each group to be irradiated. Thus, $300 \mu \mathrm{L}$ of bacterial suspension of each group were separated into three wells (100 $\mu \mathrm{L}$ per well) of a 24 -well plate, which was irradiated with blue light, and then $100 \mu \mathrm{L}$ for each well were diluted in $900 \mu \mathrm{L}$ of sterile PBS.

The plates were irradiated using the equipment and parameters described in Table 1. The control groups were processed similarly to the irradiated groups in all stages.

Table 1 Characteristics of blue light used in irradiations

\begin{tabular}{|c|c|c|c|c|}
\hline Device & $\begin{array}{l}\mathrm{N}^{\circ} \\
\text { LEDs }\end{array}$ & $\begin{array}{c}\lambda \\
(\mathrm{nm})\end{array}$ & $\begin{array}{c}\text { Power } \\
\text { density } \\
\left(\mathrm{mW} / \mathrm{cm}^{2}\right)\end{array}$ & $\begin{array}{l}\text { Energy } \\
\text { density } \\
\left(\mathrm{J} / \mathrm{cm}^{2}\right)\end{array}$ \\
\hline $\begin{array}{c}\text { Biotable } \\
\text { (Biopdi450) }\end{array}$ & 48 & 450 & 97 e 110 & $5,10,15$ e 25 \\
\hline $\begin{array}{c}\text { Biotable } \\
\text { (Homemade) }\end{array}$ & 54 & 455 & 156 & $5,10,15$ e 25 \\
\hline $\begin{array}{l}\text { Elite Olympus } \\
\text { (DMC) }\end{array}$ & 4 & 450 & 200 & $6,12,18$ e 24 \\
\hline
\end{tabular}

Source: Authors. 
Finally, the viable bacteria in the irradiated groups and controls were enumerated in BHI agar plates by serial dilution and plate counting method. The CFU counts were expressed in $\left(\log _{10} / \mathrm{ml}\right)$.

The temperatures for each power density and energy density were measured with a digital thermometer during irradiations. All tests were performed in triplicate to ensure data accuracy.

\subsection{Statistical analysis}

Data were analyzed using one-way analysis of variance (ANOVA) and Tukey statistical test (Bioestat 5.0 software) to evaluate differences between groups. A p-value of $<0.05$ was considered statistically significant.

\section{Results and Discussion}

As the objective of this study was to verify the effect of the antimicrobial action of blue light, the temperatures for each power density and energy density were measured, monitoring the thermal change during irradiations (figure 3). The temperatures were measured during irradiation. It can be observed that in Biotable homemade, $156 \mathrm{~mW} / \mathrm{cm}^{2}$, there was practically no temperature change about the increase in energy density. On the other hand, an increase in temperature was observed in the Elite (DMC) and Biopdi450 devices as the energy density increased. The highest temperature registered was $51.7^{\circ} \mathrm{C}$ in $200 \mathrm{~mW} / \mathrm{cm}^{2}$ at $24 \mathrm{~J} / \mathrm{cm}^{2}$.

Figure 1: Variation of temperature in different energy and power densities after exposure to blue light LED.

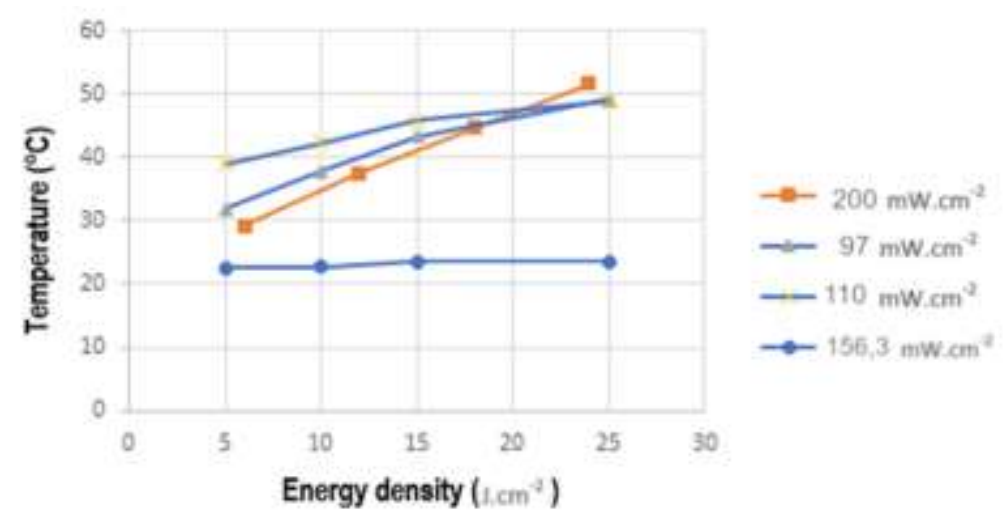

Source: Authors.

In this study, two opportunistic pathogens of the genus Staphylococcus (S. aureus and S. epidermidis) responsible for bacterial skin infections were selected as model microorganisms. In addition, the photoinactivation assays were performed, taking into account the maximum number of bacteria isolated in patients that suffered atopic dermatitis (AD) (Brown, 2020).

Thus the initial inoculums for S. aureus and S. epidermidis were $\sim 1.5 \times 10^{8}$ bacteria/mL. Next, the planktonic bacteria were exposed to blue light doses between 5 and $25 \mathrm{~J} / \mathrm{cm}^{2}$ using three light source devices (Table 1).

The results of bacterial growth after applying blue LED (Figure 2) indicate a reduction in the number of viable cells, this factor being dependent on the fluency and power density applied. For the $S$. aureus strain (Figure 2A), a more significant reduction was observed in the group treated with $5 \mathrm{~J} / \mathrm{cm}^{2}$ and $200 \mathrm{~mW} / \mathrm{cm}^{2}$, of approximately $2 \mathrm{log}$, while the treatments with 10,15 , and $25 \mathrm{~J} / \mathrm{cm}^{2}$ and $200 \mathrm{~mW} / \mathrm{cm}^{2}$, showed a slight reduction. The second most effective treatment was $5 \mathrm{~J} / \mathrm{cm}^{2}$ and 156.3 $\mathrm{mW} / \mathrm{cm}^{2}$, reducing over one log. Although a statistically significant reduction was observed in the other treatments, it cannot be considered a bactericidal effect. For this strain of S. aureus, an effect on bacterial viability dependent on the potency density 
used was demonstrated since, at the fluence of $5 \mathrm{~J} / \mathrm{cm}^{2}$ at the potency densities of 97 and $110 \mathrm{~mW} / \mathrm{cm}^{2}$, no reduction was observed in the same proportion of those treated with 156.3 and $200 \mathrm{~mW} / \mathrm{cm}^{2}$.

The observed behavior was not similar for the S. epidermidis strain (Figure 2B). The best result was achieved with 25 $\mathrm{J} / \mathrm{cm}^{2}$ and $97 \mathrm{~mW} / \mathrm{cm}^{2}$ with a reduction of approximately $1 \mathrm{log}$, while all other treatments showed a similar reduction pattern of less than one log. Therefore, for S. epidermidis, no more significant effect was demonstrated for higher power densities in any of the fluences tested.

These results demonstrate that the temperature variations observed in the study do not imply a change in the viability of both strains. The observed effects are only a result of the interaction with the LED at $450 \mathrm{~nm}$.

Figure 2. Viability evaluation of S. aureus (A) and S. epidermidis (B) in CFU/ml after applying different fluences and power densities. Symbols represent a significant difference $\mathrm{p}<0.01$ between treatments and their respective controls.

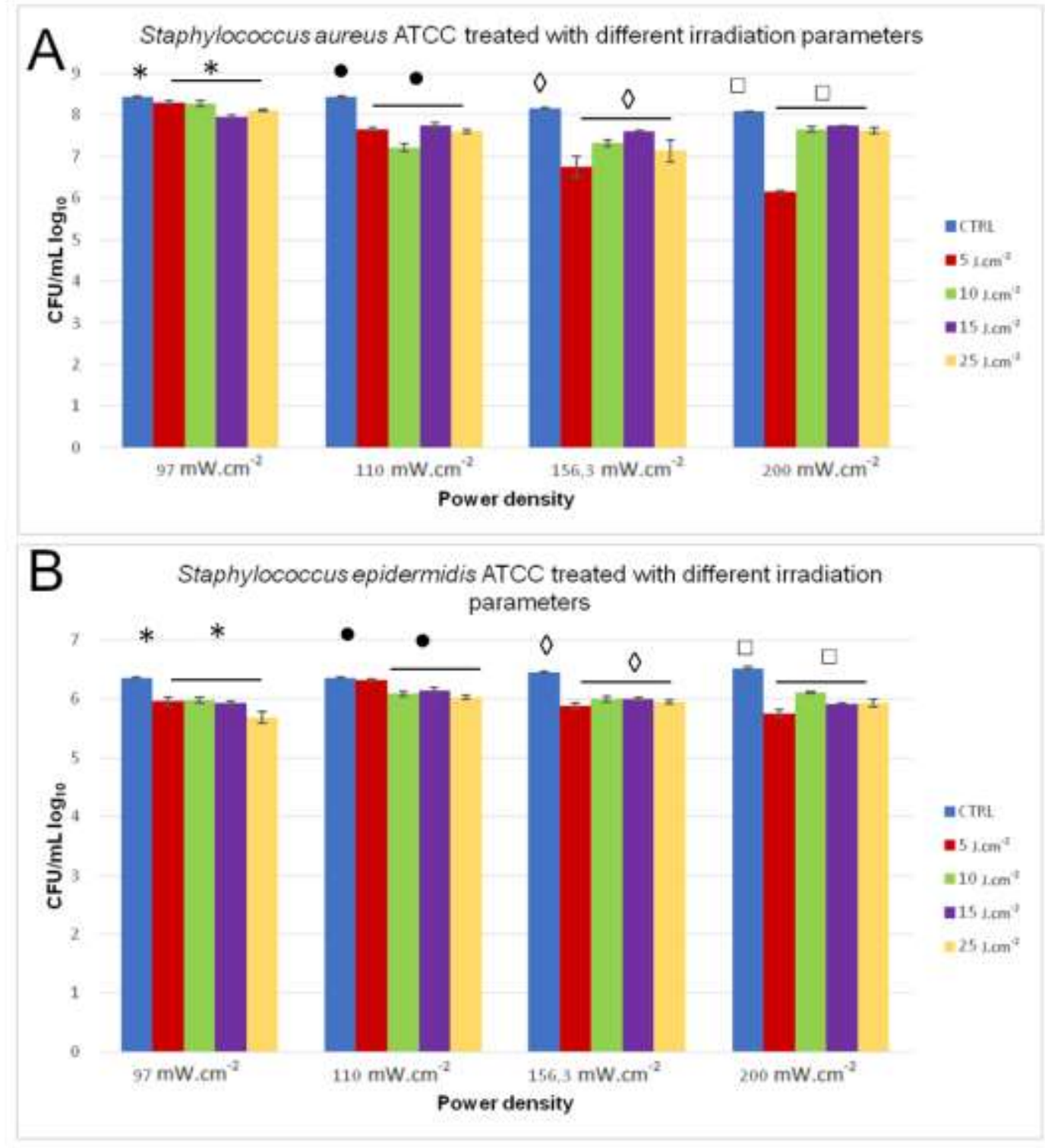

Source: Authors. 
Phototherapy involves the application of visible light using irradiation parameters considered therapeutic. These parameters involve the power density measured in $\mathrm{W} / \mathrm{cm} 2$, or $\mathrm{mW} / \mathrm{cm} 2$ is the light output power per unit area, it can also be called intensity or fluence rate; energy density measured in $\mathrm{J} / \mathrm{cm} 2$ is the amount of energy per unit area transferred to matter, also known as fluence or light dose. In addition, these parameters modulate the tissue response, either minimizing the thermal effect, stimulating or inhibiting the tissue response (Ribeiro, 2004).

In the present study, the blue LED with a wavelength of $450 \pm 10 \mathrm{~nm}$ was used to inactivate strains of S. aureus in vitro because it was demonstrated in previous studies that the values between 453 and $480 \mathrm{~nm}$ are less cytotoxic for human cells (Opländer et al., 2011; Rupel et al., 2019) and also because they are used in phototherapy equipment in the area of Aesthetics.

S. aureus is the most common pathogen in skin infections (Oyama et al., 2020; Santajit \& Indrawattana, 2016; Tong, Davis, Eichenberger, Holland, \& Fowler, 2015). At the same time, S. epidermidis is the most abundant bacterial colonizer of healthy human skin, which is attributed to an essential role in preventing skin colonization of bacterial pathogens. However, current evidence suggests that colonization by specific strains of S. epidermidis may either help or damage the skin barrier (Brown \& Horswill, 2020). Patients with AD are often highly colonized with $S$. aureus at lesional sites (7 x 106 bacteria/ $/ \mathrm{cm} 2)$. However, some studies reported that these patients could be highly colonized by S. epidermidis rather than S. aureus (Byrd et al., 2017; Hon, Tsang, Pong, Leung, \& Ip, 2016). Moreover, it has been reported that the skin inflammation severity tends to correlate with the number of bacteria in the site of infection (Travers et al., 2012). In this sense, the effectiveness of the blue light treatment was evaluated, taking into account the bacterial density present in skin infections caused by opportunistic pathogens such as $S$. aureus and $S$. epidermidis. Therefore to mimic the number of bacteria present at the lesional site during the bacterial infection, the initial inoculums of S. aureus and S. epidermidis were 1 x 107 and 106 bacteria/cm2, respectively.

The results of our work indicated that no microbial reduction above $2 \log$ was observed in the irradiated groups with power densities of $97.110,156$, and $200 \mathrm{~mW} / \mathrm{cm} 2$ at different energy densities $(5,10,15$, and $25 \mathrm{~J} / \mathrm{cm} 2)$ when compared to the control groups. There were no statistical differences with the energy density of $25 \mathrm{~J} / \mathrm{cm} 2$ between the power densities used, inferring that in this energy density, the power density, after a certain point, is not relevant for the antimicrobial effect. Other studies used parameters similar to this study $(405 \mathrm{~nm}, 100 \mathrm{~mW} / \mathrm{cm} 2$, and power densities between 1 and $60 \mathrm{~J} / \mathrm{cm} 2)$ in strains of methicillin-resistant S. aureus. In this sense, Enwemeka et al. reduced 50\% (2-fold reduction) the initial inoculum (5x106 $\mathrm{CFU} / \mathrm{mL}$ ) at $12 \mathrm{~J} / \mathrm{cm} 2$, which is in agreement with our results (Enwemeka, Williams, Hollosi, Yens, \& Enwemeka, 2008). Moreover, they observed that the microbial reduction does not double or triple at densities of $24 \mathrm{~J} / \mathrm{cm} 2$ and $36 \mathrm{~J} / \mathrm{cm} 2$, and the fluence-dependent effect is non-linear. Bumah achieved 100\% reduction with an exposure of 3x106 CFU/mL, although, with denser bacterial solutions, $5 \times 106 \mathrm{CFU} / \mathrm{mL}$, two exposures at $50 \mathrm{~J} / \mathrm{cm} 2$ were necessary to obtain the same microbial reduction.

There was no significant microbial reduction at $450 \mathrm{~nm}$, at $97 \mathrm{~mW} / \mathrm{cm} 2$, and $10-15 \mathrm{~J} / \mathrm{cm} 2$ with a single light application in this study. Comparing the results obtained by Enwemeka et al., it is believed that shorter wavelengths in the range of visible blue light are an essential parameter for the antimicrobial effect. In addition, Bumah achieved a reduction of colonies in higher energy densities, in which it is believed that there is a more preponderant thermotoxic action than the phototoxic action.

Maclean et al. achieved a $5 \log$ reduction with the parameters of $405 \mathrm{~nm}, 10 \mathrm{~mW} / \mathrm{cm} 2$, and $36 \mathrm{~J} / \mathrm{cm} 2$, but the exposure time, 60 to 90 minutes, was too long to be applied to people. (Maclean, MacGregor, Anderson, \& Woolsey, 2009).

Lipovsky et al. and Maclean et al. also achieved significant microbial reduction: $415 \mathrm{~nm}, 100 \mathrm{~mW} / \mathrm{cm} 2,120 \mathrm{~J} / \mathrm{cm} 2(90 \%$ reduction) and $400 \mathrm{~nm}, 300 \mathrm{~mW} / \mathrm{cm} 2$, and $450 \mathrm{~J} / \mathrm{cm} 2$ (3 log reduction), respectively. As the energy density used by both is relatively high, it is believed that the high thermal factor must have been an adjunct to the inhibition of bacterial growth (Lipovsky et al., 2010; Maclean, MacGregor, Anderson, \& Woolsey, 2008).

Froes et al. achieved a satisfactory microbial reduction in the treatment of folliculitis. However, the result was not only due to the application of blue light. The protocol consisted of 4 sessions, with the application of blue LED (4 Joules/40s) and 
infrared (32s), using antifoliculitis cream with ammonium lactate and essential oil of tea tree (Froes-Meyer et al., 2018).

It is important to note that all irradiated groups received a single exposure to blue light in the present study. Therefore, the temperature for each group was checked to ensure that the thermal effect was not an adjuvant factor in the inactivation of the bacteria. The temperature in the Biotable homemade remained in the range of $20-25{ }^{\circ} \mathrm{C}$, and the highest temperature reached during the exposures was $51.7^{\circ} \mathrm{C}$ with the Elite Olympus (DMC) device.

It was observed that the results in the three devices used, Biopdi450, biotable manufactured by the laboratory and Elite Olympus (DMC) - the latter used in the area of Aesthetics - were similar, suggesting that there was standard behavior of response to irradiation in the face of increased irradiation parameters, i.e., a nonsignificant reduction.

It is necessary to analyze how many irradiations are necessary to define the parameters of emission of blue light that inhibit S. aureus without causing harmful effects to human cells. In power and energy densities, the thermal effect is accentuated, and it is not desired in applications in patients in the Aesthetic area. The choice of wavelength seems relevant to avoid damage to human cells, as there are studies that report that wavelengths between $400-420 \mathrm{~nm}$ can induce different degrees of intracellular oxidative stress17. Therefore, it is recommended to use the range from 450 to $470 \mathrm{~nm}$, which is safer. However, the choice of energy and power density parameters still causes controversy among the scientific community.

\section{Conclusion}

This study demonstrated that the energy and power densities used were insufficient to cause a bactericidal effect of S. aureus planktonic cultures in a single application. Studies describe the efficacy of blue light as a promising tool to inhibit the growth of S. aureus in vitro. However, further studies are needed to establish protocols, parameters, and adjustments for the best application.

\section{Acknowledgments}

The authors would like to thank the Research and Development Institute of the University of Vale do Paraíba (IP\&D UNIVAP) and Coordination for the Improvement of Higher Education Personnel - Brazil (CAPES) - Finance Code 001.

\section{References}

Albuquerque, B. D., Santos, K. Y. K., Galan, karolline C. A., Silva, L. S. S. da, Coelho, T. A., Mariano, I. C. de S., \& Talhati, F. (2019). Tratamento estético para foliculite em homens. Pesquisa e Ação, 5, 35-39.

Ashkenazi, H., Malik, Z., Harth, Y., \& Nitzan, Y. (2003). Eradication of Propionibacterium acnes by its endogenic porphyrins after illumination with high intensity blue light. FEMS Immunology and Medical Microbiology, 35(1), 17-24. https://doi.org/10.1016/S0928-8244(02)00423-6

Barolet, D. (2008). Light-Emitting Diodes (LEDs) in Dermatology. Seminars in Cutaneous Medicine and Surgery, 27(4), 227-238. https://doi.org/10.1016/j.sder.2008.08.003

Brown, M. M., \& Horswill, A. R. (2020). Staphylococcus epidermidis-Skin friend or foe? PLoS Pathogens, 16(11), 1-6. https://doi.org/10.1371/JOURNAL.PPAT.1009026

Bumah, V. V., Masson-Meyers, D. S., Cashin, S., \& Enwemeka, C. S. (2015). Optimization of the Antimicrobial Effect of Blue Light on Methicillin-Resistant Staphylococcus aureus (MRSA) In Vitro Violet. Lasers in Surgery and Medicine, 47(3), 266-272. https://doi.org/10.1016/j.physbeh.2017.03.040

Byrd, A. L., Deming, C., Cassidy, S. K. B., Harrison, O. J., Ng, W. I., Conlan, S., \& Kong, H. H. (2017). Staphylococcus aureus and Staphylococcus epidermidis strain diversity underlying pediatric atopic dermatitis. Science Translational Medicine, 9(397), 1-22. https://doi.org/10.1126/scitranslmed.aal4651

Claudel, J. P., Auffret, N., Leccia, M. T., Poli, F., Corvec, S., \& Dréno, B. (2019). Staphylococcus epidermidis: A Potential New Player in the Physiopathology of Acne? Dermatology, 235(4), 287-294. https://doi.org/10.1159/000499858

Dai, T., Gupta, A., Huang, Y. Y., Yin, R., Murray, C. K., Vrahas, M. S., \& Hamblin, M. R. (2013). Blue light rescues mice from potentially fatal pseudomonas aeruginosa burn infection: Efficacy, safety, and mechanism of action. Antimicrobial Agents and Chemotherapy, 57(3), 1238-1245. https://doi.org/10.1128/AAC.01652-12 
Dai, T., Gupta, A., Murrayd, C. K., Vrahase, M. S., Tegosa, G. P., \& Hamblin, M. R. (2012). Blue light for infectious diseases: Propionibacterium acnes, Helicobacter pylori, and beyond? Drug Resistance Updates, 15(4), 223-236. https://doi.org/10.1016/j.drup.2012.07.001.Blue

Enwemeka, C. S., Williams, D., Hollosi, S., Yens, D., \& Enwemeka, S. K. (2008). Visible 405 nm SLD light photo-destroys methicillin-resistant Staphylococcus aureus (MRSA) in vitro. Lasers in Surgery and Medicine, 40(10), 734-737. https://doi.org/10.1002/lsm.20724

Froes-Meyer, P., Morais Carreiro, E. de, Martiniano de Medeiros, N. B., Neves dos Santos Lindenmeyer, W. R., Varela Júnior, C. A., Valetim da Silva, R. M., ... Galadari, H. (2018). Analysis of a protocol for the treatment of buttocks folliculitis. Journal of Dermatology \& Cosmetology, 2(4), 185-189. https://doi.org/10.15406/jdc.2018.02.00074

Hamblin, M. R., \& Hasan, T. (2004). Photodynamic Therapy: a new antimicrobial approach to infectious disease? Photochemical \& Photobiological Sciences, 3(5), 436-450. https://doi.org/10.1039/b311900a.Photodynamic

Hon, K. L., Tsang, Y. C. K., Pong, N. H., Leung, T. F., \& Ip, M. (2016). Exploring Staphylococcus epidermidis in atopic eczema: friend or foe? Clinical and Experimental Dermatology, 41(6), 659-663. https://doi.org/10.1111/ced.12866

Lipovsky, A., Nitzan, Y., Gedanken, A., \& Lubart, R. (2010). Visible light-induced killing of bacteria as a function of wavelength: Implication for wound healing. Lasers in Surgery and Medicine, 42(6), 467-472. https://doi.org/10.1002/1sm.20948

Lister, J. L., \& Horswill, A. R. (2014). Staphylococcus aureus biofilms: Recent developments in biofilm dispersal. Frontiers in Cellular and Infection Microbiology, 4(DEC), 1-9. https://doi.org/10.3389/fcimb.2014.00178

Maclean, M., MacGregor, S. J., Anderson, J. G., \& Woolsey, G. (2008). High-intensity narrow-spectrum light inactivation and wavelength sensitivity of Staphylococcus aureus. FEMS Microbiology Letters, 285(2), 227-232. https://doi.org/10.1111/j.1574-6968.2008.01233.x

Maclean, M., MacGregor, S. J., Anderson, J. G., \& Woolsey, G. (2009). Inactivation of bacterial pathogens following exposure to light from a 405-nanometer light-emitting diode array. Applied and Environmental Microbiology, 75(7), 1932-1937. https://doi.org/10.1128/AEM.01892-08

Monaco, M., Araujo, F. P. de, Cruciani, M., Coccia, E. M., \& Pantosti, A. (2017). Worldwide Epidemiology and Antibiotic Resistance of Staphylococcus aureus Monica. Current Topics in Microbiology and Immunology (2017), 409, 21-56. https://doi.org/10.1007/82

Oyama, J., Fernandes Herculano Ramos-Milaré, Á. C., Lopes Lera-Nonose, D. S. S., Nesi-Reis, V., Galhardo Demarchi, I., Alessi Aristides, S. M., \& Campana Lonardoni, M. V. (2020). Photodynamic therapy in wound healing in vivo: a systematic review. Photodiagnosis and Photodynamic Therapy, 30(January), 101682. https://doi.org/10.1016/j.pdpdt.2020.101682

Opländer, C., Hidding, S., Werners, F. B., Born, M., Pallua, N., \& Suschek, C. V. (2011). Effects of blue light irradiation on human dermal fibroblasts. Journal of Photochemistry and Photobiology B: Biology, 103(2), 118-125. https://doi.org/10.1016/j.jphotobiol.2011.02.018

Papageorgiou, P., Katsambas, A., \& Chu, A. C. (2000). Phototherapy with blue (415 nm) and red (660 nm) light in the treatment of acne vulgaris. British Journal of Dermatology, 142(5), 973-978. https://doi.org/10.1046/j.1365-2133.2000.03481.x

Ribeiro, M. S., \& Zezell, D. M. (2004)."Laser de baixa intensidade." A Odontologia e o laser. São Paulo: Quintessense

Rupel, K., Zupin, L., Ottaviani, G., Bertani, I., Martinelli, V., Porrelli, D., \& Zacchigna, S. (2019). Blue laser light inhibits biofilm formation in vitro and in vivo by inducing oxidative stress. Npj Biofilms and Microbiomes, 5(1), 1-11. https://doi.org/10.1038/s41522-019-0102-9

Santajit, S., \& Indrawattana, N. (2016). Mechanisms of Antimicrobial Resistance in ESKAPE Pathogens. BioMed Research International, 2016. https://doi.org/10.1155/2016/2475067

Tong, S. Y. C., Davis, J. S., Eichenberger, E., Holland, T. L., \& Fowler, V. G. (2015). Staphylococcus aureus infections: Epidemiology, pathophysiology, clinical manifestations, and management. Clinical Microbiology Reviews, 28(3), 603-661. https://doi.org/10.1128/CMR.00134-14

Travers, J. B., Kozman, A., Yao, Y., Ming, W., Yao, W., Turner, M. J., \& Chandan Saha. (2012). Treatment outcomes of secondarily impetiginized pediatric atopic dermatitis lesions and the role of oral antibiotics. Pediatric Dermatology, 29(3), 289-296. https://doi.org/10.1038/jid.2014.371 